\title{
Pro-Kontra dalam Mengamalkan Hadis Ahad Sebagai Otoritas Agama Islam
}

\author{
Syahidin Syahidin'1, Agusri Fauzan², Ilham Syukri \\ ${ }^{123}$ Institut Agama Islam Negeri Bengkulu \\ e-mail: syahidin@iainbengkulu.ac.id
}

\begin{abstract}
Based on the quantity of narrators, hadith is divided into two, namely mutawatir and Ahad. Most of the teachings of Islam, be it creed or other problems, rely on the hadith ahad. If the ahad hadith cannot be used as evidence, then the consequence is that many Islamic teachings that are understood and believed by the majority of Muslims so far will be displaced. The discourse categorization of hadiths into mutawatir and Ahad will have an impact on the emergence of doubts and even rejection of the authority of the hadiths as a source of Islamic teachings after the Qur'an, which also means doubting most of the traditions of the Prophet Muhammad. This study aims to see the pros and cons. in practicing the hadith ahad. The method used in this research is a qualitative method through the documentation of data collection techniques, this technique is carried out by examining documents related to the authenticity of the ahad hadith in some hadith literature and other works. The data analysis is descriptive analysis and comparative. The results of the research show that even though these ahad hadiths do not show conviction, he shows them to strong suspicion, and they have become the legal basis before the mutawatir-ahad dichotomy appeared. In fact, the opinion that states that these ahad traditions cannot be used as evidence, even in matters of faith, is the opinion of bid'ah, has no basis in Islamic syari'at. The status of ahad hadith authenticity is consensus accepted through the arguments that have been explained by the scholars to refute some of the scholars who reject it.
\end{abstract}

Keywords: Hadith Ahad, Discourse, Authority, legitimate

\begin{abstract}
Abstrak
Berdasarkan kuantitas perawi, hadis terbagi menjadi dua yaitu mutawatir dan ahad. Sebagian besar ajaran Islam baik itu akidah ataupun masalah lainnya bersandar kepada hadis ahad. Jika hadis ahad tidak dapat dijadikan hujjah, maka konsekuensinya adalah banyak ajaran Islam yang dipahami dan diyakini mayoritas muslim selama ini akan tergusur. Diskursus kategorisasi hadis menjadi mutawatir dan ahad akan berdampak terhadap munculnya keraguan bahkan penolakan terhadap otoritas hadis ahad sebagai sumber ajaran Islam setelah setelah Al-Qur'an, yang juga berarti telah meragukan sebagian besar hadis Rasulullah saw.. Penelitian ini bertujuan untuk melihat pro-kontra dalam mengamalkan hadis ahad. Metode yang digunakan dalam penelitian ini adalah metode kualitatif melalui teknik pengumpulan data dokumentasi, teknik ini dilakukan dengan telaah pada dokumendokumen yang terkait dengan kehujjahan hadis ahad pada beberapa literatur ilmu hadis dan juga karya lainnya. Analisis data bersifat deskriptis analisis dan komparatif. Hasil Penelitian menunjukkan hadis-hadis ahad ini sekalipun tidak menunjukkan kepada yakin, namun la menunjukkan kepada zann al-ghalib (dugaan kuat), dan telah menjadi dasar hukum sebelum dikotomi mutawatir-ahad muncul. Sesungguhnya pendapat yang menyatakan bahwa hadis-hadis ahad itu tidak bisa dijadikan hujjah bahkan dalam masalah akidah adalah pendapat bid'ah, tidak ada dasarnya dalam syari'at Islam. Status kehujjahan hadis ahad adalah diterima secara konsesus melalui argumentasi yang sudah dijelaskan oleh para ulama untuk membantah sebagian ulama yang menolaknya.
\end{abstract}

Kata Kunci: Hadis Ahad, Diskursur, Otoritas, Kehujjahan 


\section{Pendahuluan}

Dalam sejarah keberadaan dan perkembangannya, hadis telah dihadapkan pada beberapa tantangan dan berbagai situasi yang diwarnai aneka ragam perselisihan pendapat di kalangan para ulama. Munculnya kategorisasi hadis menjadi mutawatir dan ahad pada paruh awal abad ketiga hijriah menjadi titik awal lahirnya perdebatan dan perbedaan pandangan mengenai keabsahan hadis sebagai dasar syariat Islam khususnya terhadap hadis yang berkategori ahad.

Pembedaan hadis antara yang ahad dan mutawatir belum muncul pada masa Rasulullah dan para sahabat. Para sahabat Rasulullah saw. menerima hadis dari seseorang yang meriwayatkan kepada mereka setelah jelas status dan kredibilitas penyampainya. Pembedaan tersebut baru muncul pada masa tabi'in dan sesudahnya. ${ }^{1}$ Menurut Ibn Hazm (w. 456 $\mathrm{H})$, seluruh umat Islam menerima hadis dari satu orang yang terpercaya hingga datangnya para ahli ilmu kalam Mu'tazilah yang mengambil sikap berbeda

Persoalan ini tidak kunjung selesai, sejak periode klasik sampai sekarang tetap menjadi persoalan yang sering diperdebatkan. Penentuan diterima atau tidaknya hadis tersebut sebagai hujjah

${ }^{1}$ Lihat 'Abd al-Muhdi 'Abd al-Qadir, Daf'u alShubuhat 'An al-Hadith al-Nabawi (Kairo: Maktabah alIman, 2010), 84 atau sumber ilmu dan amal sangatlah penting untuk dikaji dan ditelusuri. Terlebih lagi sebagian besar hadis adalah hadis yang berkategori ahad dan sangat sedikit jumlah hadis mencapai tinggkat mutawatir. Logika yang bisa kita tangkap dari itu adalah, bahwa sebagian besar ajaran Islam bersandar kepada hadis ahad. Jika hadis ahad tidak dapat dijadikan hujjah, maka konsekuensinya adalah banyak ajaran Islam yang dipahami dan diyakini mayoritas muslim selama ini akan tergusur. ${ }^{2}$

Diskursus kategorisasi hadis menjadi mutawatir dan ahad pada akhirnya berdampak terhadap munculnya keraguan bahkan penolakan terhadap otoritas hadis ahad sebagai sumber ajaran Islam setelah setelah Al-Qur'an, yang juga berarti telah meragukan sebagian besar hadis Rasulullah saw. Hal ini dikarenakan sebagian besar hadis adalah hadis ahad.

Tujuan dari penulisan artikel ini adalah: 1. Melihat kronologis sejarah munculnya istilah hadis ahad dan mutawatir, 2. Meilhat kontropersi yang disebabkan penolakan hadis ahad dan konsekuensi hukum yang akan ditimbulkan dari penolakan tersebut, 3 . Hasil ijma dan pembelaan ulama serta

2 Lihat Ali Mustafa Yaqub, Kritik Hadis (Jakarta: Pustaka Pirdaus, cet. Ke-5, 2008), 133. 
argumentasi yang diajukan dalam pembelaan kehujjahan hadis ahad.

\section{Hasil dan Pembahasan}

\section{Kategorisai Hadis Menjadi Mutawatir dan Ahad}

Berdasarkan jumlah perawinya hadis terbagi menjadi dua yaitu hadis mutawatir dan hadis ahad. Hadis mutawatir adalah hadis yang diriwayatkan oleh sekelompok orang banyak pada setiap tingkat periwayatnya, mulai dari tingkat sahabat sampai dengan pengarang kitab yang menurut akal dan kebiasaan tidak mungkin mereka sepakat berdusta ${ }^{3}$. Sedangkan hadis ahad secara bahasa kata aahad merupakan bentuk jama' dari ahadun yang berarti satu. Maka kata aahad berarti satu-satu. Dari pengertian secara bahasa ini, sepintas bisa diketahui bahwa hadis ahad adalah hadis yang diriwayatkan oleh seorang perawi. Angka satu memberi kesan akan jumlah yang sedikit. Dengan demikian bisa dikatakan juga hadis ahad adalah hadis yang diriwayatkan oleh perawi yang sedikit. Dalam istilah ilmu hadis, hadis

${ }^{3}$ Syahidin, Syahidin. "Kehujjahan Hadis Ahad Menurut Muhammad Al-Ghazali (Suatu Kajian terhadap Otoritas Hadis Ahad sebagai Sumber Ajaran Islam)." ElAfkar: Jurnal Pemikiran Keislaman dan Tafsir Hadis 6.1 (2017): 61-70. ahad berarti hadis yang jumlah perawinya tidak mencapai derajat hadis mutawatir. ${ }^{4}$

Ada sebagian ulama yang menyatakan bahwa hadis mutawatir jumlahnya sangat sedikit. Hal itu disebabkan karena sulitnya terpenuhi kriteria dan syarat-syarat hadis mutawatir yang sangat ketat. Ibn al-Shalah misalnya, ia beranggapan bahwa hadis muatwatir itu hanya sedikit, bahkan ada orang yang berlebihan sehingga beranggapan bahwa hadis mutawatir itu sama sekali tidak ada. Akan tetapi ulama hadis yang lain seperti Ibn Hajar al-Asqalani tidak sependapat dengan pernyataan tersebut, menurutnya pendapat itu muncul akibat dari sedikitnya perhatian terhadap sanadsanad hadis. Lebih lanjut Ibn Hajar menuturkan bahwa menetapkan banyaknya hadis mutawatir sebenarnya caranya cukup mudah dan jelas, suatu cara untuk menetapkan bahwa hadis mutawatir itu ada dan jumlahnya banyak adalah dengan melihat ketika mereka sepakat mengeluarkan suatu hadis dengan sanad yang banyak sehingga menurut adat mustahil mereka bersepakat untuk berdusta, maka hadis itu dapat diyakini keasliannya dari pembicaranya. Hadis yang seperti ini banyak terdapat dalam

"Ibn Shalah, Muqaddimah Ibn Shalah Fi 'Ulum alHadith (Bairut: Dar al-Kutub al-'Ilmiyyah, 2003), 241. Lihat juga: 
kitab-kitab hadis yang masyhur dan keberadaanya sudah beredar di seluruh penjuru dunia. ${ }^{5}$

$$
\text { Pendapat senada juga }
$$

dikemukakan oleh Nuruddin 'Itr salah seorang ulama hadis kontemporer. Ia menuturkan bahwa hadis mutawatir itu banyak sekali, cukup sebagai buktinya dengan melihat beberapa syiar Islam dan beberapa kewajiban dalam Islam, seperti shalat, wudhu', dan puasa. Semua tata cara itu diriwayatkan oleh para sahabat dari Nabi saw., lalu diriwayatkan dari para sahabat oleh sejumlah tabiin yang mencapai derajat mutawatir dan begitu seterusnya pada generasi-generasi berikutnya. ${ }^{6}$ Untuk menunjukkan bahwa hadis mutawatr ini jumlahnya banyak, ada beberapa ulama yang menyusun kitab khusus memuat hadis mutawatir. Seperti Imam Suyuti dengan kitabnya yang berjudul al-Azhar al-Mutanaa tsirah fi alAkhbar al-Mutawatirah. Muhammad ibn Ja'far al-Kattani dengan kitabnya yag berjudul Nazm al-Mutanathir min al-Hadith al-Mutawatir dan beberapa kitab yang lainnya.

\section{Awal Mula Munculnya Mutawatir-Ahad}

5Ibn Hajar al-Asqalani, Nuzhah al-Nazar fi Taudhih Nukhbat al-Fikr fi Musthalahi Ahl al-Atsar (Damshiq: Matba'ah al-Syabah, cetakan ke 3, 2000), 45-46.

${ }^{6}$ Nuruddin 'Itr, 'Ulum al-Hadith terj. Drs. Mujiyo, (Bandung: PT. Remaja Rosdakarya, 2012), 432.
Menurut Ibn Hazm (w. 456 H), sesungguhnya seluruh kaum muslimin dahulunya menerima hadis ahad, yakni hadis yang diriwayatkan oleh perawi yang 'adil dan dapat dipercaya. Lebih lanjut ibn Hazm menuturkan bahwa semua golongan melakukan itu, sampai kemudian muncul Mu'tazilah satu abad sesudah hijriyah, lalu menetang ijma' tersebut. $^{7}$

Kaum Mu'tazilah berpendapat bahwa hadis ahad itu tidak dapat memberikan kepastian ilmu dan meyakinkan informasi. Sementara justifikasi hukum berdasarkan logika menurut mereka adalah pasti, sehingga bisa dijadikan acuan dalam hukum syariat. Dengan alasan itu menurut mereka hukum logika harus didahulukan dari hadis ahad secara mutlak, baik dalam persoalan akidah maupun ibadah praktis. Bahkan dalam masalah akidah mereka menolak seluruh hadis ahad secara totalitas, dengan alasan bahwa persoalan akidah harus dibangun melalui sumber yang bersifat absolut dan pasti, bukan berdasarkan sumber yang bernilai zhann seperti hadis ahad. 8

\section{Penolakan Hadis Ahad pada Masa Klasik}

7Salim 'Ali al-Bahanasawi, al-Sunnah al-Muftara' 'Alaiha (Kuwait: Dar al-Buhuth al-'Ilmiyah, 1992), 140.

${ }^{8}$ Muhammad Hamid al-Nasir, al-'Asraniyyun bayn Maza'im al-Tajdid wa Mayadin al-Taghrib, terj. Abu Umar Bashir, (Jakarta: Darul Haq, 2004), 22. 
Menurut $\mathrm{Mu}^{\prime}$ tazilah, hadis ahad tidak bisa dikategorikan sebagai Sunnah, kecuali dalam sebuah konteks pengenalan dan tentunya setelah diketahui relevansinya dengan logika. Oleh sebab itu, menurut logika tidak bisa disebutkan misalnya, "Rasulullah bersabda", namun harus disebutkan, "Diriwayatkan dari Nabi". Akibat dari semua itu adalah bahwa kaum Mu'tazilah menolak banyak sekali persoalan akidah yang bersumber dari hadis ahad, seperti tentang siksa kubur, mengimani adanya telaga Nabi saw, adanya al-sirat, al-mizan (timbangan untuk amal perbuatan), shafa'at, dan masalah melihat Allah di akhirat. Mereka juga menolak banyak hukum-hukum syariat yang sah dengan alasan bertentangan dengan logika dan kontradiktif dengan Al-Qur'an, atau berlawanan dengan hadis-hadis lain. Itulah beberapa contoh penyimpangan Mu'tazilah yang disebutkan oleh Ibn Qutaibah (w. $276 \mathrm{H}$ ) yang dikutip oleh Abd al-Qahir al-Baghdadi dalam kitabnya al-Farq bayna al-Firaq. ${ }^{9}$

Di antara tokoh Mu'tazilah yang mengingkari dan tidak menerima hadis ahad baik dalam masalah akidah maupun hukum syar'i adalah Abu Hasan al-

9al-Nashir, al-'Asraniyyun bayn Maza'im al-Tajdid, 23. Litah juga Abd al-Qahir al-Baghdadi, al-Farq bayn alFiraq, (Bairut: Maktabah al-'Asriyyah, 1995), 127-142.
Khayyath. Begitu juga Abu Huzail Ali alJubbai sebagaimana dikatakan al-Maziri dan lainnya, disebut sebagai orang yang tidak mau menerima hadis, jika hanya diriwayatkan oleh satu perawi adil. Menurutnya hadis seperti ini baru dapat diterima dengan syarat, apabila hadis tersebut diperkuat oleh hadis yang diriwayatkan oleh rawi 'adil lainnya, teks hadis tersebut dikuatkan oleh teks hadis lainnya atau teksnya tidak bertentangan dengan teks Al-Qur'an, kemudian hadis tersebut paling tidak diamalkan oleh sebagian sahabat. ${ }^{10}$

Sebagian dari kalangan Mu'tazilah tidak hanya mengingkari keberadaan hadis ahad, tetapi juga terhadap hadis mutawatir, seperti yang dilakukan oleh alNazzam yang berpendapat bahwa boleh saja terjadi kebohongan dalam hadis mutawatir sekalipun tidak terbilang jumlah para periwayatnya, karena lain tujuan dan motivasi. Oleh karena itu, ia menolak hadis mutawatir dan ijmak, karena boleh jadi umat berkonsensus dalam membuat kesalahan. Demikian juga terhadap hadis ahad yang tidak memberi pengertian ilmu secara pasti. ${ }^{11}$ Sementara

${ }^{10} \mathrm{Abu}$ Lubabah Husain, Mauqif al-Mu'tazilah min al-Sunnah al-Nabawiyah, terj. Usman Sy'roni (Jakarta: Pustaka Firdaus, 2003), 77-78.

${ }^{11}$ Abdul Majid Khon, Pemikiran Modern dalam Sunnah; Pendekatan Ilmu Hadis (Jakarta: Prenada Media Grop, 2011), 51. Lihat juga Abd al-Qa>hir al-Baghdadi, alFarq bayn al-Firaq, (Bairut: Maktabah al-'Asriyyah, 1995), 158-159. 
itu, Abu Huzail berpendapat bahwa kehujjahan khabar tentang berita yang non indrawi (seperti tanda-tanda kenabian dan lain-lain) jumlah perawinya tidak boleh kurang dari 20 orang dan di dalamnya terdapat sebagian ahli surga sekalipun terdapat orang kafir dan fasik. Jika di dalamnya tidak terdapat satu atau sebagian ahli surga sekalipun jumlahnya mutawatir dan tidak mungkin sepakat berbohong, tidak dapat dijadikan hujjah. Jumlah periwayat yang kurang dari empat orang tidak dapat memberi hukum apaapa, dan jika perwainya 4-20 orang periwayat, ada kalanya memberi faedah kepastian (ilmu) dan adakalanya tidak. ${ }^{12}$

Selain Mu'tazilah, kaum Syi’ah Rafidhah, manyoritas kelompok Qadariyah dan juga tentang al-Qasani serta ibn Dawud mereka juga disebutsebut sebagai yang mengingkari kehujjahan hadis perorangan (hadis ahad). ${ }^{13}$ Lebih lanjut al-Qasani mengatakan bahwa hadis ahad tidak menghasilkan sesuatu kecuali yang hanya bersifat zann, dan sesuatu yang zann tidak dapat memberikan kepastian kepada kebenaran sedikitpun. ${ }^{14}$

51

${ }^{12}$ Majid Khon, Pemikiran Modern dalam Sunnah,

${ }^{13}$ Mustfa al-Siba'i, al-Sunnah wa Makanatuha fi alTashri'i al-Islami (t.tp: Dar al-Waraq, 2000), 142.

${ }^{14}$ Muhammad bin Ali al-Shaukani, Irshad alFuhul ila Tahqiq al-Haq min 'Ilm al-Usul (Riyad\}: Dar alFadilah, 2000), 39.
Masalah utama yang membuat mereka menolak hadis ahad adalah karena hadis ahad dari segi wurud-nya hanyalah bersifat zanni al-wurud, dalam arti kebenaran berita tersebut dari Rasulullah saw. tidak dapat diyakini secara pasti sebagaimana hadis mutawatir. Menurut mereka, urusan agama haruslah didasarkan kepada dalil-dalil qath'i yang tingkat kebenaranya dapat diyakini dan dipastikan. Oleh karena itu hanya AlQur'an dan hadis mutawatir saja yang dapat dijadikan hujjah dalam masalah agama. ${ }^{15}$

Penolakan sebagian kelompok terhadap kehujjahan hadis ahad sebagaimana yang diprakarsai oleh sebagian kelompok Mu'tazilah, Rafid\}ah, dan Qadariyah seperti yang telah dijelaskan sebelumnya, sangat erat kaitannya dengan gerakan ingkar sunnah yang muncul pada masa klasik, yakni pada masa imam al-Shafi'i. Imam alShafi'i ${ }^{16}$ menyebut adanya kelompok munkir al-sunnah atau inkar sunnah. Namun demikian al-Syafi'i tidak menjelaskan secara eksplisit siapa saja orang yang menolak sunnah itu. Secara garis besar ada tiga kelompok pengingkar sunnah yang berhadapan dengan al-

${ }^{15}$ Rif'at Fauzi Abd al-Mutalib, Tauthiq al-Sunnah fi Qarn al-Tsani al-Hijr; Asasuhu wa Ijtijahatuhu (Kairo: Maktabah al-Khanaji, 1983), 90.

${ }^{16}$ Muhammad bin Idris al-Shafi'i, al-Risalah (t.tp: Must\}afa al-Halabi, t.th.), 369-387. 
Shafi'i, yaitu; Pertama kelompok yang menolak sunnah secara keseluruhan, golongan ini hanya mengakui Al-Qur'an saja yang dapat dijadikan hujjah. Kedua kelompok yang tidak menerima sunnah kecuali yang semakna dengan Al-Qur'an. Ketiga kelompok yang menerima hadis mutawatir saja dan menolak hadis ahad.

Menurut Muahammad al-Khudari Bik, kelompok yang mengingkari Sunnah yang dimaksud imam al-Syafi'i adalah kelompok ahli kalam Mu'tazilah. Pendapat ini berdasarkan adanya diskusi antara imam al-Syafi'i dengan kelompok yang mengingkari sunnah. Sementara kelompok atau aliran yang ada pada waktu itu di Basrah Iraq (tempat imam alSyafi'i berada) adalah Mu'tazilah. Dengan ini al-Khudari Bik berkesimpulan bahwa kelompok yang ingkar sunnah yang dimaksud al-Syafi'i adalah kelompok Mu'tazilah. ${ }^{17}$

Sedangkan Mustafa al-Siba'i juga sependapat dengan pendapat al-Khudari Bik tersebut. Lalu pertanyaannya adalah apakah Mu'tazilah menolak Sunnah secara keseluruhan, atau hanya menolak sebagiannya saja? Ada sementara ulama $\mathrm{Mu}^{\prime}$ tazilah yang tampaknya menolak sunnah secara keseluruhan, yaitu Abu Ishaq Ibrahim bin Sayyar, yang popular

${ }^{17}$ Lihat Ali Mustafa Yaqub, Kritik Hadis (Pustaka Firdaus, cetakan ke-5, 2008), 43. dengan sebutan al-Nazzam. Ia tidak hanya mengingkari hadis ahad, tetapi juga mengingkari hadis yang mutawatir. Menurutnya ada kemugkinan sekelompok orang untuk bersepakat berdusta meskipun diriwayatkan oleh sejumlah perawi yang tidak terhingga bilangannya. Namun demikain, menurut Mushthafa al'Azami, pendapat al-Nazzam tersebut tidaklah mencerminkan sikap kelompok Mu'tazilah secara keseluruhan. Menurutnya, apabila pendapat al-Nazzam ini dapat diartikan sebagai penolakan hadis, maka tampaknya hal itu hanyalah pendapat pribadinya saja dan bukan merupakan pendapat resmi Mazhab Mu'tazilah. Alasannya, ada ulama Mu'tazilah yang lain yang ternyata menerima hadis sebagai sumber shari'ah Islam, misalnya Abu al-Hasan al-Bashri dalam kitabnya al-Mu'tamad. Bahkan ada beberapa ulama Mu'tazilah yang lain, seperti Abu Huzail, Muhammad bin Abd al-Wahhab al-Jubba'i, justru menilai bahwa al-Nazzam telah keluar dari Islam. ${ }^{18}$

Oleh Karen itu, Mazhab Mu'tazilah tidak dapat disebut pengingkar sunnah, tetapi sebaliknya, mereka menerima Sunnah seperti halnya mayoritas umat Islam. Hanya saja,

${ }^{18}$ Mustfa al-Siba'i, al-Sunnah wa Makanatuha fi Tashri'i al-Islami (t.tp: Dar al-Waraq, 2000), 169-174. 
mungkin ada beberapa hadis yang mereka kritik apabila hal itu berlawanan dengan pemikiran mazhab mereka. Namun demikian hal itu tidak berarti mereka menolak hadis secara keseluruhan.

\section{Pembelaan Imam al-Syafi'i Terhadap} Hadis Ahad

Imam al-Syafi'i yang dikenal sebagai nashir al-Sunnah (pembela Sunnah), memiliki peran yang sangat penting dalam menundukkan kelompok pengingkar Sunnah. Dalam kitabnya alUmm al- al-Syafi'i menuturkan perdebatannya dengan orang-orang yang menolak hadis. Setelah melalui perdebatan yang panjang, rasional, dan ilmiyah akhirnya kelompok pengingkar sunnah bertekuk lutut dan mengakui kehujjahan sunnah. ${ }^{19}$

Terkait dengan pembelaan al-Syafi' $\mathrm{i}$ terhadap kehujjahan hadis ahad, al-Syafi'i membahasnya secara khusus dalam kitabnya al-Risalah di bawah judul Bab Khabar al-Wahid. Ia menjelaskan dengan penjelasan yang sangat jelas dan rasional, serta dengan dalil-dalil yang akurat baik dari Al-Qur'an, Sunnah ataupun amal perbuatan para sahabat, tabi'in, tabi' tabi'in, dan bahkan juga para ahli fikih

${ }^{19}$ Muhammad bin Idris al-Shafi'i, al-Umm (Bairut: Dar al-Ma'rifah, 1973), 273. Lihat juga Musthafa al-Siba'i, al-Sunnah wa Makanatuha fi Tashri'i al-Islami (t.tp: Dar al-Waraq, 2000), 108.
Islam lainnya. Dengan semua alasan tersebut, al-Syafi'i menetapkan wajibnya mengamalkan hadis ahad dan menjadikannya sebagai hujjah dalam maslah agama. ${ }^{20}$ Pendapat al- Shafi'i ini adalah pendapat mayoritas ulama hadis dan merupakan ijmak ulama salaf.21 $\mathrm{Al}$ Siba'i menuturkan bahwa al-Razi mengklaim dalam kitabhnya al-Mahsul bahwa para sahabat telah bersepakat akan hal itu. Lebih lanjut al-Siba'i menjelaskan pendapat ulama lain seperti Ahmad ibn Hanbal, al-Harith bin Asad al-Muhasibi, al-Husen Ali al-Karabisi, Abu Sulaiman bahwa mereka berpendapat hadis ahad itu bersifat pasti dan menjadi sumber ilmu dan amal sekaligus. Mereka semua sepakat tentang kehujjahan hadis ahad dan wajib mengamalkannya. 22

\section{Pengingkaran Hadis Ahad pada Era Modern}

Penolakan terhadap kehujjahan hadis ahad tidak hanya terjadi pada masa klasik (era Mu'tazilah). Kalangan modernis juga melancarkan syubhat yang sama, yaitu menolak kehujjahan hadis

${ }^{20}$ Muhammad bin Idris al-Shafi'i, al-Risalah (Bairut: Dar al-Kutub al-'Ilmiyah, juz. 2, t.th), 369-471.

21 Agusri Fauzan,. "Pengujian Hadits Ahad Dengan Al-qur'an (Studi Komparatif Syafi'iyyah dan Hanafiyah)." Manhaj: Jurnal Penelitian dan Pengabdian Masyarakat 8.1 (2019):

${ }^{22}$ Musthafa al-Siba'i, al-Sunnah wa Makanatuha fi al-Tashri'i al-Islami (t.tp: Dar al-Warq, 2000), 141. Lihat juga Al-Amidi, Al-Ihkam fi Usul al-Ahkam (Bairut: Dar al-Kitub al-'Arabi, 1992, juz. 1), 108. 
ahad. Kalau pada masa klasik penolakan terhadap hadis ahad dipelopori oleh Mu'tazilah, maka di abad modern ini dipelopori oleh Muhammad Abduh, Mahmud Shaltut, Muhammad Abu Zahrah, Abu Rayyah, Ahmad Amin dan yang lainnya. ${ }^{23}$ Di antara mereka ada yang menolaknya secara mutlak dan ada yang menolak kehujjahannya dalam masalah akidah, sebagaimana yang dinyatakan oleh para pendahulu mereka. Ahmad Amin misalnya, Ia berpendapat bahwa hadis ahad, yaitu hadis selain mutawatir tidak memberi faedah ilmu (yakin) menurut mayoritas ulama ushul alfigh dan fikih. Sesungguhnya ia boleh diamalkan ketika kuat dugaannya. ${ }^{24}$ Begitu juga dengan Abu Rayyah, menurutnya hadis ahad ditolak dengan alasan pendapat jumhur bahwa ia tidak dapat memberi ilmu secara pasti sekalipun dikeluarkan oleh al-Bukhari dan Muslim, kebenarannya hanya bersifat dugaan. Dalam banyak ayat-ayat al-Quran kita diperintahkan untuk menjauhi zhann. ${ }^{25}$

Abu Rayyah dalam menolak sunnah (khususnya hadis ahad) banyak merujuk kepada pendapat Muhammad

23 Ali Musthafa Yaqub, Kritik Hadis (Pustaka Firdaus, cetakan ke-5, 2008), 46-47.

${ }^{24}$ Ahmad Amin, Fajr al-Islam cet. Ke-2 (Kairo: Maktabah al-Nahdah al-Misriyah, 1975), 218.

${ }^{25} \mathrm{Abu}$ Rayyah, Adwa 'ala al-Sunnah (Kairo: Dar al-Ma'arif. tth), 250.
Abduh dan Rasyid Rid\}a. Sehingga kedua tokoh ini disebut-sebut sebagai pengingkar sunnah. Namun benarkah Muhammad Abduh mengingkari Sunnah? Musthafa al-'Azami kelihatannya mebenarkan hal itu, dengan cacatan apabila kesimpulan Abu Rayyah dalam kitabnya Adwa 'ala al-Sunnah alMuhammadiyah itu benar. ${ }^{26}$ Begitu juga Musthafa al-Siba'i, secara tidak langsung ia menuduh Muahammad Abduh sebagai pengingkar Sunnah dan menilainya sebagai orang yang sedikit perbendaharaan hadisnya. Menurut alSiba'i Muhammad Abduh memilik prinsip bahwa senjata yang paling ampuh membela Islam adalah logika dan argumen yang rasional. Berangkat dari prinsip ini Abduh kemudian mempunyai penilaian lain terhadap kedudukan Sunnah. Pendapat Abduh ini akhirnya dijadikan argumen kuat oleh Abu Rayyah dalam mengingkari Sunnah ${ }^{27}$.

Menurut Ali Mustafa Yaqub, sebenarnya keterangan Muhammad Abduh sebagaimna yang dinukil Abu Rayyah itu masih perlu ditinjau kembali. Masalahnya, boleh jadi Abduh ketika mengatakan hal itu didorong oleh semangat yang menggebu-gebu untuk

${ }^{26}$ Muhammad Musthafa al-Azami, Hadis Nabi dan Sejarah Kodifikasinya, terj. Ali Mustafa Yuqub (Jakarta: Pustaka Pirdaus, cet. 3, 2006), 46.

${ }^{27}$ Musthafa al-Siba'i, al-Sunnah wa Makanatuha fi Tashri'i al-Islami (t.tp: Dar al-Waraq, 2000), 122. 
membumikan ajaran Al-Qur'an, sehingga ia sampai berpendapat bahwa selain $\mathrm{Al}-$ Qur'an tidak ada gunanya sama sekali. Namun bagaimanapun Abduh telah dituduh sebagai pengingkar Sunnah. Lebih lanjut Mustafa Yaqub menuturkan bahwa ada suatu hal yang kongkrit tentang Muhammad Abduh dalam kaitannya dengan hadis, yaitu Abduh menolak hadis ahad untuk dijadikan dalil dalam masalah akidah. ${ }^{28}$

Senada dengan Abduh, Mahmud Shaltut berkali-kali menegaskan bahwa hadis ahad tidak dapat dipakai dalam masalah-masalah akidah, dengan alasan hadis ahad tidak menghasilkan keyakinan. Masalah akidah adalah masalah yang harus diimani dan diyakini, oleh karena itu akidah harus didasarkan kepada keterangan yang pasti yang tidak ada keraguan di dalamnya. Ini berarti riwayat mutawatir saja yang dapat diterima untuk menetapkan masalah akidah, sedangkan hadis ahad tidak dapat dijadikan dasar dalam menetapkan akidah, karena ia tidak dapat memberikan pengertian yang pasti, ia hanya mengasilkan zann semata. ${ }^{29}$ Begitu juga Muhammad al-Ghazali, ia menegaskan bahwa sesungguhnya akidah itu dasarnya adalah keyakinan yang

${ }^{28}$ Ali Mustafa Yaqub, Kritik Hadis (Pustaka Firdaus, cetakan ke-5, 2008), 48.

${ }^{29}$ Mahmud Shaltut, al-Islam 'Aqidah wa Shari'ah (Kairo: Dar al-Shuruq, 2001), 58-59. bersih yang tidak ternodai oleh keraguraguan. Bagaimanpun juga, Islam dibangun di atas dalil-dalil yang akurat dan dalil logika yang kuat. Tidak ada istilah akidah bagi kami yang hanya dibangun di atas dasar hadis ahad dan tebak-tebakan pikiran semata. ${ }^{30}$

\section{Pendapat Jumhur Ulama Terhadap Hadis} Ahad

Sedangkan ahli hadis dan jumhur ulama berpendapat bahwa hadis ahad yang telah memenuhi syarat kesahihan sebuah hadis, maka wajib mengamalkannya, pengamalan hadis ahad tersebut berlaku untuk seluruh masalah agama baik akidah maupun masalah lainnya. Para sahabat dan orangorang sesudahnya yang terdiri dari para tabi'in dan generasi Salaf umat ini, baik yang mengatakan, bahwa hadis ahad itu menunjukkan ilmu yang yakin maupun yang berpendapat hadis ahad menunjukkan zann, mereka berijma' (sepakat) atas wajibnya mengamalkan hadis ahad, tidak ada yang berselisih dari mereka kecuali sebagian Mu'tazilah dan Rafidhah. ${ }^{31}$ Terkait dengan hal ini, Khatib al-Baghdadi menjelaskan bahwa

${ }^{30}$ Muhammad al-Ghazali, Al-Sunnah alNabawiyah baina Ahl al-Figh wa Ahl al-Hadith (Kairo: Dar alShuruq, 2005), 66.

${ }^{31}$ Muhammad Hamid al-Nasir, al-'Asraniyyun bayn Maza'im al-Tajdid wa Mayadin al-Taghrib, terj. Abu Umar Bashir, (Jakarta: Darul Haq, 2004), 223. 
keharusan mengamalkan hadis ahad itu adalah pendapat seluruh tabi'in dan para fuqaha sesudahnya di seluruh negeri hingga kini. Tidak ada keterangan yang sampai kepada kami tentang adanya salah seorang dari mereka yang menentangnya atau menyalahinya. ${ }^{32}$

Ibn al-Qayyim menuturkan, bahwa hadis-hadis ahad ini sekalipun tidak menunjukkan kepada yakin, namun la menunjukkan kepada zann al-ghalib (dugaan kuat), boleh bagi kita untuk menetapkan asma' dan sifat-sifat Allah dengannya sebagaimana tidak ada larangan menggunakannya untuk menetapkan hukum-hukum yang sifatnya perintah atau larangan. Jika ada yang membedakan, maka pembedaan itu adalah batil berdasarkan ijma' para ulama. Kemudian Ibn al-Qayyim lebih lanjut menjelaskan bahwa para ulama salaf dan ahli hadis senantiasa mengambil hadishadis ahad sebagai dasar berargumentasi dalam masalah-masalah sifat, takdir, Asma Allah, dan hukum. Tidak ada satu pun riwayat yang menyebutkan ada satu orang dari mereka yang membolehkan berargumentasi dan berhujjah dengan hadis-hadis ahad untuk masalah hukum,

${ }^{32} \mathrm{Abu}$ Bakar Ahmad bin 'Ali bin Thabit alKhatib al-Baghdadi, al-Kifayah fi 'Ilm al-Riwayah (Bairut: Dar al-Kutub al-Ilmiyah, 1988), 72. tapi melarangnya untuk masalah-masalah akidah. 33

Senada dengan Ibn al-Qayyim, Nasiruddin al-Albani menegaskan, sesungguhnya pendapat yang menyatakan bahwa hadis-hadis ahad itu tidak bisa dijadikan hujjah dalam akidah adalah pendapat bid'ah, tidak ada dasarnya dalam syari' at Islam yang penuh dengan kebajikan. Itu adalah pendapat aneh menurut petunjuk Al-Qur'an dan bimbingan Sunnah bahkan belum dikenal oleh para al-salaf al-shalih. Pendapat itu hanya dilontarkan oleh segolongan ulama kalam dan sebagian ulama usul yang kemudian mempengaruhi pemikiran sebagian ulama kontemporer. Lalu pendapat itu diambil begitu saja oleh kaum modernis dengan pasrah, tanpa penyangkalan atau argumetasi yang jelas. Kemudian lebih lanjut al-Albani menuturkan, kalau pendapat itu diambil, berarti ada ratusan hadis sahih yang harus ditolak karena berkaitan dengan akidah. ${ }^{34}$

\section{Kesimpulan}

Pembedaan hadis antara yang ahad dan mutawatir belum muncul pada masa Rasulullah dan para sahabat. Para

\footnotetext{
${ }^{33}$ Ibn Qayyim al-Jauziyah, Mukhtasar al-Sawa'iq al-Mursalah 'ala al-Jahmiyah al-Mu'attalah (Riyad): Maktabah Ad\}wa al-Salaf, juz. 2, 2004), 412.

${ }^{34}$ Muhammad Nasiruddin al-Albani, al-Hadith Hujjah bi Nafsihi fi al-'Aqaid wa al-Ahkam (Kuwait: Dar alSalafiyyah, 1987), 54-55.
} 
sahabat Rasulullah saw. menerima hadis dari seseorang yang meriwayatkan kepada mereka setelah jelas status dan kredibilitas penyampainya. Pembedaan tersebut baru muncul pada masa tabi' in dan sesudahnya. Menurut Ibn Hazm (w. $456 \mathrm{H})$, seluruh umat Islam menerima hadis dari satu orang yang terpercaya hingga datangnya para ahli ilmu kalam Mu'tazilah yang mengambil sikap berbeda.

hadis-hadis ahad ini sekalipun tidak menunjukkan kepada yakin, namun la menunjukkan kepada zann al-ghalib (dugaan kuat), dan telah menjadi dasar hukum sebelum dikotomi mutawatir-ahad muncul. Sesungguhnya pendapat yang menyatakan bahwa hadis-hadis ahad itu tidak bisa dijadikan hujjah bahkan dalam masalah akidah adalah pendapat bid'ah, tidak ada dasarnya dalam syari'at Islam yang penuh dengan kebajikan. Itu adalah pendapat aneh menurut petunjuk $\mathrm{Al}-$ Qur'an dan bimbingan Sunnah bahkan belum dikenal oleh para al-salaf al-shalih. Pendapat itu hanya dilontarkan oleh segolongan ulama kalam dan sebagian ulama usul yang kemudian mempengaruhi pemikiran sebagian ulama kontemporer.

Apa yang dikemukan oleh Muhammad Nasiruddin al-Albani, menurut penulis sangatlah beralasan, karena sebagian besar hadis adalah hadis yang berkategori ahad dan sangat sedikit jumlah hadis yang mencapai tingkat mutawatir. Logika yang bisa ditangkap dari itu adalah, bahwa sebagian besar ajaran Islam baik itu akidah ataupun masalah lainnya bersandar kepada hadis ahad. Jika hadis ahad tidak dapat dijadikan hujjah, maka konsekuensinya adalah banyak ajaran Islam yang dipahami dan diyakini mayoritas muslim selama ini akan tergusur.

\section{Referensi}

1. 'Abduh, Mahmud. Muhammad alGhazali Da'iyah an-Nahdah alIslamiyyah. cet. 1. Beirut: Markaz alHadarah li Tanmiyah al-Fikr al-Islami, 2009.

2. Abdul Khaliq, Abdul Ghani. Difa' 'An al-Sunnah wa Rad Shubhah alMustashriqin wa al-Kuttab alMua'sirin. Bairut: Dar al-Jail, 1991.

3. Abu Bakar, Umar. Syaikh Nas\}iruddin al-Albani dalam Kenangan. Solo: AtTibyan, t.th.

4. al-Albani, Muhammad Nasiruddin. al-Hadith Hujjah bi Nafsihi fi al'Aqaid wa al-Ahkam. Kuwiat: Dar alSalafiyyah, 1987.

5. Amin, Ahmad. Fajr al-Islam. Kairo: Maktabah al-Nahdah al-Misriyah, 1975.

6. al-Amidi, Abu al-Hasan. al-Ihkam fi Ushul al-Ahkam. Bairut: Dar al-Fikr, 1996.

7. al-Asqalani, Ibnu Hajar. Nuzhah alNazar fi Taudhih Nukhbat Ahl al-Fikr fi Mustalahi Ahl al-Atsar. Maktabah Mishkah,tth.

8. Azami, Muhammad Musthafa. Hadis Nabawi dan Sejarah Kodifikasinya, 
terj. Ali Mustafa Yaqub. Jakarta: Pustaka Firdaus, 2006.

9. Fauzan, Agusri. "Studi Komparatif Teori Ilmu Hadis Al-Hakim AlNaisaburiy dan Ibnu Shalah." ElAfkar: Jurnal Pemikiran Keislaman dan Tafsir Hadis 7.1 (2018): 51-68.

10. Fauzan, Agusri. "Pengujian Hadits Ahad Dengan Al-qur'an (Studi Komparatif Syafi'iyyah dan Hanafiyah)." Manhaj: Jurnal Penelitian dan Pengabdian Masyarakat 8.1 (2019):

11. al-Ghazali, Muhammad. Al-Sunnah al-Nabawiyah baina Ahl al-Fiqh wa Ahl al-Hadith. Kairo: Dar al-Shuruq, 2005.

12. Ibn al-Salah. Muqaddimah Ibn alShalah fi 'Ulum al-Hadith. Bairut: Dar al-Kutub al-'Ilmiyyah, 2003.

13. Ismail, M. Syuhudi. Metodologi Penelitian Hadis Nabi. Jakarta: Bulan Bintang, 2007.

14. 'Itr, Nuruddin. 'Ulum al-Hadith, terj. Drs. Mujiyo. Bandung: Remaja Rosdakarya, 2012.

15. al-Syafi'i . Muhammad bin Idris, alRisalah. Kairo: Must afa al-Halbi, tth.

16. Syahidin, Syahidin. "Kehujjahan Hadis Ahad Menurut Muhammad AlGhazali (Suatu Kajian terhadap Otoritas Hadis Ahad sebagai Sumber Ajaran Islam)." El-Afkar: Jurnal Pemikiran Keislaman dan Tafsir Hadis 6.1 (2017): 61-70.

17. Syahidin, Syahidin. "Penolakan Hadis Ahad Dalam Tinjauan Sejarah Ingkar Sunnah." Tsaqofah dan Tarikh: Jurnal Kebudayaan dan Sejarah Islam 3.2 (2018): 179-187.

18. Yaqub, Ali Mustafa. Kritik Hadis. Jakarta: Pustaka Pirdaus, 2008. 